W hy should a cataloger care about library advocacy? How does advocacy help my library? Isn't advocacy the role of the library dean? These and more questions were explored at the "Advocacy from the front lines" symposium, hosted by Mississippi State University (MSU) Libraries on February 16 . The symposium drew more than 40 librarians from five universities for the daylong exploration of advocacy in academic libraries. ACRL President Camila Alire was the keynote speaker.

\section{Advocacy from the front lines}

The workshop opened with remarks by Dean Frances Coleman and MSU Provost Peter Rabideau. Both stressed the importance of academic libraries and the role that advocacy can play in promoting the library to multiple constituencies. Camila Alire then gave the keynote address on advocacy in today's academic library.

Alire addressed some of the common misconceptions about front-line advocacy. Front-line advocacy is everyone's responsibility, not just that of the library director or upper-level administrators. While advocacy is a key component to any contemporary library dean, this level of advocacy is usually targeted to comparable level administrators (or higher) across campus. As Alire pointed out in her September 2005 CERL News article, "frontline, grassroots advocacy is having those academic library staff-who are working with students and faculty on a daily basis and who already have the competency and credibility in dealing with their customers-take the leadership in advocating for the library at the campus level." Who better to take on this role than the men and women working at the circulation desk, serving on committees across campus with faculty, or teaching a library instruction class? And Alire emphasized that advocacy was everyone's responsibility, not just the librarians. The library "team" comprised of administrators, librarians, staff, and students all have a role to play in developing and implementing a successful advocacy program.

These daily opportunities to build support for the library can have tremendous payoffs, but they do require an investment on the part of the library. Everyone must feel empowered to serve as advocates for the library. Successful advocacy requires training, including the development of a library advocacy plan with a succinct and consistent message. Realistically, not everyone will be suited to be a successful library advocate, but those who are willing to take on this role need to be recognized for the contribution they make to the library.

Next, Associate Dean for Public Services Harry LLull set the stage for the afternoon session. LLull provided some background information about the advocacy movement and challenged the workshop participants to think of advocacy in terms of both librarians and library professionals.

\section{Breakout group topics}

It's one thing to listen to someone else talk about advocacy; it's another to try to come

Deborah Lee is associate professor/coordinator of library instructional services and associate director of the Center for Teaching and Learning at Mississippi State University, e-mail: dlee@library.mssstate.edu

(c) 2006 Deborah Lee 


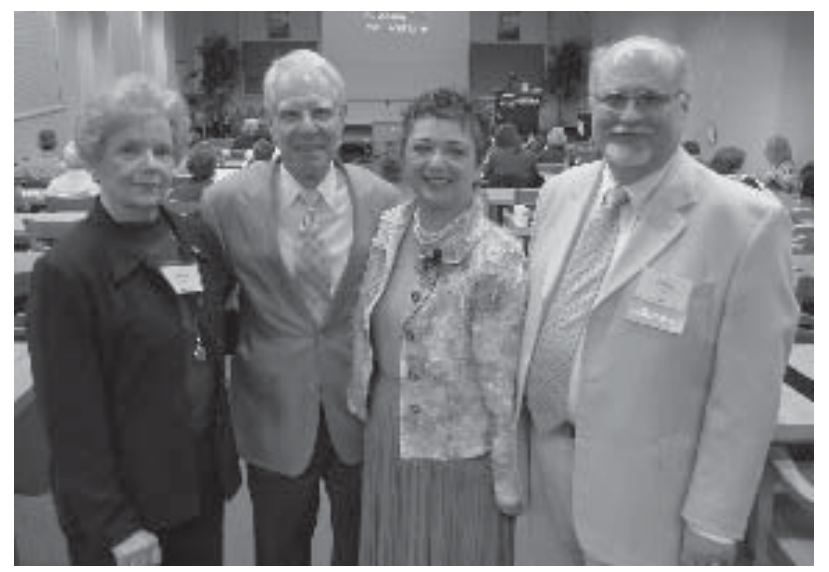

Speakers at the Advocacy from the Front Line Symposium included Dean Frances Coleman, Provost Peter Rabideau, ACRL President Camila Alire, and Associate Dean Harry LLull.

up with programs that put these principles in place. Librarians are natural problem solvers. To help the participants fully explore various dimensions of advocacy from the front line, five scenarios depicting common advocacy challenges were developed for use in breakout session groups. Participants divided into groups to address the following topics and then returned to the entire group to share the results of their discussions. Alire served as the facilitator of the afternoon session, prompting each group to fully discuss its topic and ask questions about the proposed programs.

Each group explored one of five scenarios:

1) Your library has decided to initiate a program focusing on high- and mid-level administrators and the information needs they may have personally or as part of their administrative duties. This adopt-an-administrator program is meant to be proactive and to demonstrate to administrators across campus the value of the information services of the library. Develop a plan of action to implement such a program. What should be emphasized and what training or mentoring of librarians would be needed? How would such a program work as part of the library's advocacy platform?

2) Your library has set a long-term goal of interacting with new teaching faculty beginning with recruitment and following through to tenure. Develop a plan of action to implement such a program. Identify the different stages from recruitment to tenure and the type of services or programs that might be helpful for new faculty through those stages. How could the library use such a program as an advocacy initiative?

3) Your library has noticed that although the electronic library is showing increasing use, there has been a decrease in the use of the physical library. Librarians are having less and less direct contact with students. Develop a student library advocacy program that will go to the students where they are and create awareness among students as to how librarians could help them be more effective and efficient in carrying out their class assignments.

4) Your library feels there is a need to make faculty more aware across campus of the very specialized expertise library faculty have in the areas of technical services, systems, and special collections. Develop an advocacy program that could be implemented that would address the needs of teaching faculty in the area of organizing, accessing, and preserving their personal collections. What type of advocacy role would be appropriate for these areas?

5) The collections in your library are going more and more electronic with less and less physical materials for both serials and books. Your library wants to implement an advocacy program that will inform teaching faculty of the new roles of library faculty as the library, its collections, and services go through this transformation. Develop a plan of action that explains to teaching faculty the new roles and services in the library for this changing environment. How could such an advocacy program also inform faculty of the need for the library to be allocated more resources to make this transformation?

How did this afternoon session work out? Fantastic! The members of each group represented different libraries and different areas within the library. The resulting group presentations offered innovative ideas for addressing each aspect of advocacy. Group one proposed the development of an "A-Team" for administrators that could serve as information 
first responders. Group two came up with a hilarious scenario that took new faculty "from blind date to golden anniversary." The group proposed a plan for working with faculty that began with the interview process (before hire) and ran through the point of retirement. Group three came up with strategies for reaching students through advocacy initiatives, including slogans such as "Like Lowe's, We Can Show You How!"

Group four attacked one of the more often asked questions concerning advocacy-how does advocacy affect those folks who work behind the scenes, providing valuable but often unacknowledged services, such as cataloging, systems, and archives. The group came up with innovative suggestions for creating unique alliances with administrators and faculty that could illustrate the importance of access, organization, and preservation of information. Group five tackled the issue of the electronic library and the changing roles of librarians.

In each case, Alire questioned the group about its proposed strategy, sometimes introducing a new element to the challenge. How can these approaches help libraries in times of tight (or reducing) budgets? What strategic alliances do these types of initiatives encourage? How would each group prioritize the work of advocacy with other work in the library?

Participants loved the opportunity to tackle realistic advocacy challenges and many indicated they hope to continue these discussions in their own libraries. One group found they liked their proposed solution so well that they have continued their exploration of the problem and hope to publish an article on the topic soon. Overall, the participants found that the symposium challenged their assumptions about advocacy and provided the foundation for a continued examination of advocacy issues in academic libraries.

\section{Note}

1. Camila A. Alire, "Advocating to advance academic libraries: The 2005-2006 ACRL President's focus" CERL News, vol. 66, no. 8 (September 2005): 590-91, 614. „2

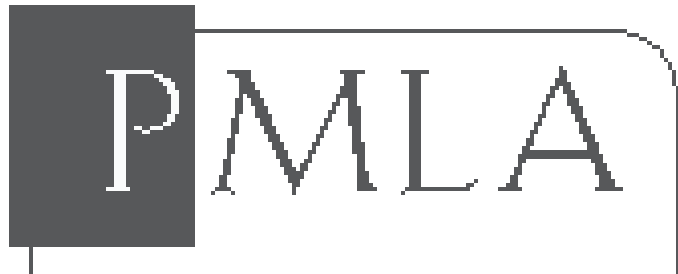

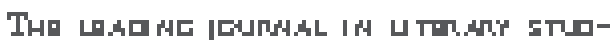

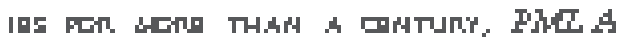

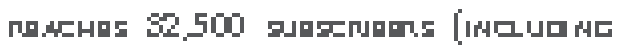

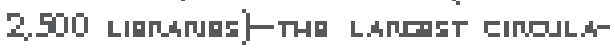

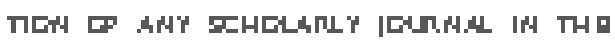

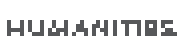

\section{Better Yilue Pricind}

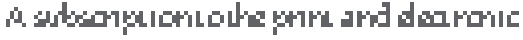

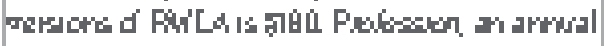

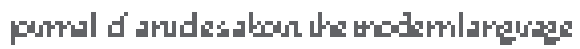

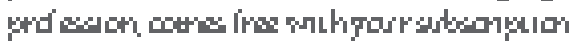

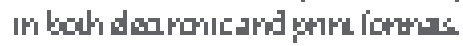

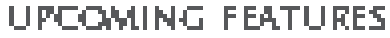

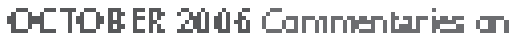

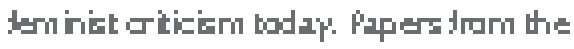

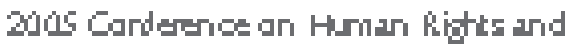
中ıe Hunuritice.

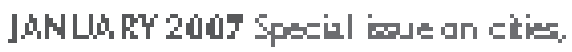

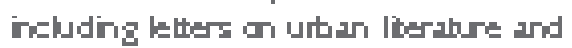
alture tam amind the wark.

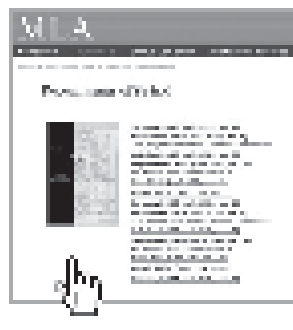

FWLA IS NOWH ONLINE Gatiringmase

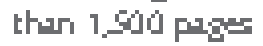

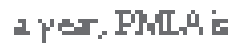
suilut k kan all mijs guteription

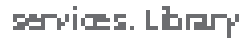

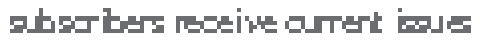

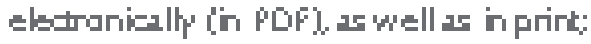
200r abguters will aba reocire all

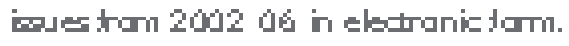

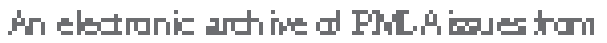

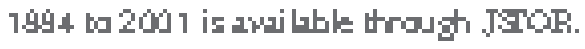

\section{FFEE TFIAL 5UESCFIFTION}

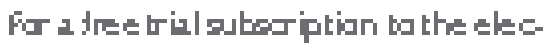

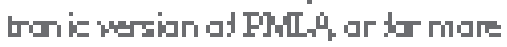
iddatus in, pleses wite a all Ltrar'

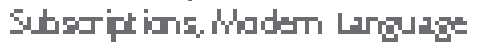

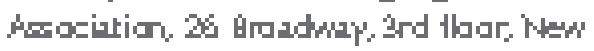

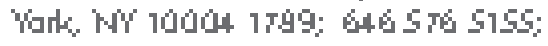

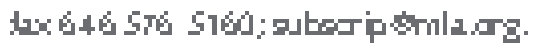

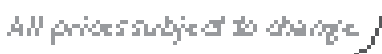

